\title{
Analisis Pertumbuhan Laba (Studi Kasus Rasio Cael Pada LPD Kecamatan Sukawati Kabupaten Gianyar)
}

\author{
Made Pratiwi Dewi ${ }^{1}$ dan Ni Luh Anik Puspaningsih ${ }^{2}$ \\ Fakultas Ekonomi dan Bisnis, Universitas Warmadewa, Denpasar-Bali, Indonesia \\ ${ }^{1}$ Email: pratiwidewi_88@yahoo.com \\ ${ }^{2}$ Email: anikpuspa168@yahoo.com
}

\section{How to cite (in APA style):}

Dewi, M,P., \& Puspaningsih, N, L, A.(2020). Analisis Pertumbuhan Laba (Studi Kasus Rasio Cael Pada LPD

Kecamatan Sukawati Kabupaten Gianyar). Warmadewa Management and Business Journal, 2(2) pp.73-83

\begin{abstract}
Abstrak :
Lembaga Perkreditan Desa (LPD) merupakan salah satu lembaga keuangan milik Desa Pekraman di Bali. Lembaga Perkreditan Desa (LPD) beroperasi seperti perbankan dan pengukuran kinerja (tingkat kesehatannya) seperti bank, walaupun LPD tersebut bukanlah bank. Pertumbuhan laba yang positif mencerminkan LPD mampu berkembang dalam operasionalnya. Penelitian ini bertujuan untuk mengetahui pengaruh Capital, Asset, Earning, dan Liquidity (CAEL) terhadap pertumbuhan laba LPD. Studi empiris dilakukan pada LPD di Kecamatan Sukawati tahun 2015-2017 dengan jumlah sampel 28 LPD. Data penelitian adalah data sekunder yang diperoleh dari Lembaga Pemberdayaan Lembaga Perkreditan Desa (LPLPD) Kabupaten Gianyar dan beberapa dari LPD secara langsung. Teknik analisis menggunakan regresi linier berganda dengan uji t (untuk mengetahui pengaruh variabel independen terhadap variabel dependen secara parsial). Hasil penelitian menunjukkan bahwa CAR

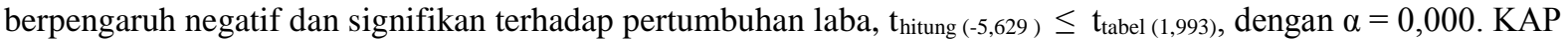
berpengaruh positif dan signifikan terhadap pertumbuhan laba, $t_{\text {hitung }(3,819)}>\mathrm{t}_{\text {tabel }}(1,993)$, dengan $\alpha=0,000$. ROA berpengaruh positif dan signifikan terhadap pertumbuhan laba $t_{\text {hitung }(5,676)}>t_{\text {tabel }}(1,993)$, dengan $\alpha=0,000$. Rasio Alat Likuid berpengaruh positif dan signifikan terhadap pertumbuhan laba, $t_{\text {hitung }(4,926)}>t_{\text {tabel }(1,993)}$, dengan $\alpha=$ 0,000 .
\end{abstract}

Kata kunci: LPD, CAEL, pertumbuhan laba

\section{PENDAHULUAN}

Bali memiliki sebuah lembaga keuangan yang disebut Lembaga Perkreditan Desa (LPD). Keberadaan Lembaga Perkreditan Desa (LPD) diatur dalam Peraturan Daerah Nomor 4, Tahun 2012, perubahan kedua atas Peraturan Daerah Provinsi Bali Nomor 8, Tahun 2002 tentang Lembaga Perkreditan Desa (LPD). Peraturan daerah ini menggariskan bahwa LPD adalah lembaga perkreditan desa yang merupakan badan usaha keuangan milik desa yang melaksanakan kegiatan usaha di lingkungan desa dan untuk krama desa. Kegiatan utama LPD adalah menghimpun dana dari masyarakat berupa tabungan dan deposito, dan menyalurkan kembali kepada masyarakat yang membutuhkan dana dalam bentuk pinjaman atau kredit. Bantuan dalam bentuk pinjaman atau kredit telah banyak membantu meningkatkan kesempatan berusaha bagi masyarakat pedesaan. LPD sebagai lembaga keuangan desa mempunyai karakteristik khusus yang berbeda dengan lembaga keuangan lainnya, sehingga dalam operasionalnya perlu dilakukan pembinaan dan pengawasan. Lembaga yang berfungsi untuk memberikan pembinaan teknis, pengembangan serta pelatihan bagi LPD adalah Lembaga Pemberdayaan LPD (LPLPD).

Mengingat pentingnya peran LPD dalam pembangunan ekonomi di masyarakat pedesaan, maka LPD perlu ditopang dengan administrasi dan pembukuan untuk mempertebal kepercayaan masyarakat akan keberadaan LPD. Selain itu LPD juga perlu menyampaikan hasil kerjanya dalam bentuk laporan keuangan yang memadai sehingga dapat memberikan informasi kepada pihak-pihak yang berkepentingan, dan dengan laporan keuangan tersebut juga dapat 


\section{Analisis Pertumbuhan Laba \\ (Studi Kasus Rasio Cael Pada LPD Kecamatan Sukawati Kabupaten Gianyar)}

memberikan gambaran mengenai kinerja keuangan LPD serta dapat mengetahui tentang hasil yang telah dicapai oleh LPD. Kinerja keuangan salah satunya dapat dinilai melalui pertumbuhan laba. Masing-masing LPD memiliki tingkat perkembangan yang berbeda-beda. Pertumbuhan laba dapat dilihat melalui laporan keuangan. Cara untuk mengevaluasi dan menginterpretasikan data laporan keuangan adalah melalui analisis rasio keuangan. Pertumbuhan laba yang positif mengindikasikan bahwa LPD berkembang dan mampu melaksanakan fungsinya.

Pertumbuhan laba adalah perubahan persentase kenaikan laba yang diperoleh LPD. Pertumbuhan laba yang baik mengisyaratkan bahwa LPD mempunyai keuangan yang baik yang pada akhirnya akan meningkatkan nilai LPD, dengan demikian mengetahui pertumbuhan laba yang diperoleh LPD sangat penting. LPD dengan laba bertumbuh akan memiliki jumlah aktiva yang besar sehingga memberikan peluang lebih besar dalam menghasilkan profitnya. Berdasarkan Peraturan Daerah Provinsi Bali No. 8 tahun 2002, tentang Lembaga Perkreditan Desa (LPD) sebagaimana telah diubah beberapa kali terakhir dengan Peraturan Daerah Provinsi Bali No. 4 tahun 2012 tentang perubahan kedua atas Peraturan Daerah Provinsi Bali No. 8 tahun 2002, dijelaskan tata cara untuk mengukur tingkat kesehatan Lembaga Perkreditan Desa (LPD). Tingkat kesehatan LPD Pada dasarnya dinilai dengan pendekatan kuantitatif atas lima faktor yang berpengaruh terhadap kondisi dan perkembangan LPD sebagai lembaga keuangan, yaitu permodalan, kualitas aktiva produktif, manajemen, earning atau rentabilitas, dan likuiditas. Kelima faktor tersebut sering disebut CAMEL (Capital, Asset, Manajement, Earning, Likuidity) (Peraturan Daerah Propinsi Bali No. 4 : 2012). Untuk Lembaga Perkreditan Desa (LPD) aspek manajemen tidak dianalisis.

Keputusan Gubernur Bali No : 95/01-C/HK/2003 tanggal 12 Maret 2003 tentang pelimpahan wewenang dan pengawasan Lembaga Perkreditan Desa di Provinsi Bali kepada PT Bank Pembangunan Daerah Bali, manajemen LPD dipilih dan dinilai secara kualitatif oleh Desa Adat melalui peparuman/rapat adat. Manajemen LPD dipercayakan langsung kepada Desa Adat setempat, sehingga untuk menganalisis kinerja kesehatan LPD digunakan analisis CAEL yang terdiri dari Capital (CAR), Assets (Kualitas Aktiva Produktif atau KAP), Earning (Rentabilitas) dan Liquidity (Likuiditas) berdasarkan Surat Keputusan Direksi PT. Bank Pembangunan Daerah Bali No. 0193.02.10.2007.2 tanggal 5 Juni 2007 tentang Pedoman Sistem Penilaian ter-hadap Lembaga Perkreditan Desa (LPD). Teori ini juga digunakan dalam penelitian terdahulu yang dilakukan oleh (Dewi, Made Rusmala, I Ketut Suwarta, 2014), yang mengukur tingkat kesehatan LPD dengan rasio CAEL (Capital, Assets, Earning, dan Likuidity). Melihat juga perkembangannya, saat ini telah banyak LPD yang berdiri di masingmasing kecamatan salah satunya adalah LPD di Kecamatan Sukawati. LPD Kecamatan Sukawati terdiri dari 33 LPD, yang tersebar di 12 desa dinas di Kecamatan Sukawati. Masingmasing LPD di Kecamatan Sukawati memiliki pertumbuhan laba yang berbeda-beda, dalam tabel 1 berikut disajikan data laba LPD Kecamatan Sukawati tahun 2015 sampai 2017.

\section{Tabel 1}

Laba pada LPD Kecamatan Sukawati Tahun 2015-2017 (dalam Rupiah)

\begin{tabular}{|r|l|r|r|r|}
\hline \multirow{2}{*}{ No } & \multicolumn{2}{|c|}{ Nama LPD } & \multicolumn{3}{|c|}{ Laba } \\
\cline { 3 - 5 } & & $\mathbf{2 0 1 5}$ & \multicolumn{1}{c|}{$\mathbf{2 0 1 6}$} & \multicolumn{1}{c|}{$\mathbf{2 0 1 7}$} \\
\hline 1 & LPD Batuaji & 733.368 .000 & 743.757 .000 & 708.162 .000 \\
\hline 2 & LPD Batuan & 1.781 .472 .000 & 2.090 .410 .000 & 2.103 .599 .000 \\
\hline 3 & LPD Batuyang & 1.260 .476 .000 & 1.275 .342 .000 & 1.294 .975 .000 \\
\hline 4 & LPD Belaluan & 127.652 .000 & 170.641 .000 & 121.894 .000 \\
\hline 5 & LPD Blang Kaler & 15.078 .000 & 11.769 .000 & 23.643 .000 \\
\hline
\end{tabular}


Analisis Pertumbuhan Laba

(Studi Kasus Rasio Cael Pada LPD Kecamatan Sukawati Kabupaten Gianyar)

\begin{tabular}{|r|l|r|r|r|}
\hline 6 & LPD Blang Samu & - & - & 322.000 \\
\hline 7 & LPD Celuk & 5.171 .253 .000 & 5.155 .425 .000 & 5.615 .365 .000 \\
\hline 8 & LPD Cemenggaon & 1.050 .858 .000 & 1.101 .120 .000 & 1.189 .697 .000 \\
\hline 9 & LPD Dlod Tukad & 144.209 .000 & 191.350 .000 & 212.618 .000 \\
\hline 10 & LPD Ganggangan Cangi & 506.190 .000 & 571.739 .000 & 636.568 .000 \\
\hline 11 & LPD Gerih & 16.370 .000 & 21.539 .000 & 21.113 .000 \\
\hline 12 & LPD Griya Kutri & - & 1.835 .000 & 6.981 .000 \\
\hline 13 & LPD Guwang & 2.438 .417 .000 & 2.457 .818 .000 & 2.550 .000 .000 \\
\hline 14 & LPD Jero Kuta & 1.669 .673 .000 & 1.920 .491 .000 & 2.107 .113 .000 \\
\hline 15 & LPD Kebon Singapadu & 214.808 .000 & 236.148 .000 & 251.276 .000 \\
\hline 16 & LPD Kemenuh & 533.775 .000 & 438.572 .000 & 566.815 .000 \\
\hline 17 & LPD Ketewel & 3.456 .016 .000 & 3.500 .742 .000 & 3.666 .215 .000 \\
\hline 18 & LPD Kutri, Singapadu & 107.694 .000 & 121.545 .000 & 111.949 .000 \\
\hline 19 & LPD Lantangidung & 68.365 .000 & 88.970 .000 & 97.124 .000 \\
\hline 20 & LPD Lembeng & 897.511 .000 & 566.242 .000 & 870.411 .000 \\
\hline 21 & LPD Negara & 244.325 .000 & 288.666 .000 & 350.789 .000 \\
\hline 22 & LPD Negari & 447.816 .000 & 517.364 .000 & 527.901 .000 \\
\hline 23 & LPD Rangkan & 350.081 .000 & 360.542 .000 & 373.498 .000 \\
\hline 24 & LPD Silakarang & 353.696 .000 & 370.433 .000 & 448.435 .000 \\
\hline 25 & LPD Singapadu & 314.248 .000 & 461.810 .000 & 512.473 .000 \\
\hline 26 & LPD Sukawati & 57.215 .000 & 91.926 .000 & 109.681 .000 \\
\hline 27 & LPD Sumampan & 900.000 .000 & 900.000 .000 & 1.140 .031 .000 \\
\hline 28 & LPD Tangsub & 84.500 .000 & 103.044 .000 & 81.920 .000 \\
\hline 29 & LPD Tegal Tamu & 659.288 .000 & 682.569 .000 & 854.618 .000 \\
\hline 30 & LPD Tegenungan & 130.834 .000 & 141.467 .000 & 164.087 .000 \\
\hline 31 & LPD Tengkulak Kaja & 756.475 .000 & 761.866 .000 & 805.047 .000 \\
\hline 32 & LPD Tengkulak Klod & 52.813 .000 & 47.908 .000 & 67.170 .000 \\
\hline 33 & LPD Tengkulak Tengah & 25.046 .000 & 27.220 .000 & 37.777 .000 \\
\hline Sula & & & \\
\hline
\end{tabular}

Sumber : LPLPD Gianyar

Berdasarkan data yang disajikan pada tabel 1 diatas dapat diketahui bahwa laba yang dihasilkan LPD di Kecamatan Sukawati setiap tahunnya mengalami fluktuasi. Dari 33 LPD di Kecamatan Sukawati ada 5 LPD dengan laporan keuangan yang tidak lengkap yaitu LPD Griya Kutri, LPD Gerih, LPD Blang Kaler, LPD Blang Samu dan LPD Tengkulak Klod. Selain itu juga dapat diketahui LPD mana yang pertumbuhan labanya baik dari tahun ke tahun. Pokok permasalahan dalam penelitian ini adalah: Bagaimanakah pengaruh rasio CAEL terhadap pertumbuhan laba di LPD Kecamatan Sukawati tahun 2015 - 2017?

\section{TELAAH LITERATUR DAN KAJIAN PUSTAKA Pertumbuhan Laba}

Pertumbuhan laba yang baik mengisyaratkan bahwa LPD mempunyai keuangan yang baik yang pada akhirnya akan meningkatkan nilai LPD, dengan demikian mengetahui pertumbuhan laba yang diperoleh LPD sangat penting. LPD dengan laba bertumbuh akan memiliki jumlah aktiva yang besar sehingga memberikan peluang lebih besar dalam menghasilkan profitnya. Pertumbuhan laba yang digunakan dalam penelitian ini adalah laba tahun berjalan. (Sari, 2015) dalam penelitiannya juga menggunakan teori pertumbuhan laba yang membandingkan laba periode tertentu dikurangi laba periode sebelumnya, lalu dibagi laba periode sebelumnya. Dalam penelitian yang dilakukannya rasio pertumbuhan laba yang digunakan dinilai efektif. 


\section{Analisis Pertumbuhan Laba \\ (Studi Kasus Rasio Cael Pada LPD Kecamatan Sukawati Kabupaten Gianyar)}

\section{Pengaruh Capital Adequacy Ratio (CAR) pada Pertumbuhan Laba}

CAR adalah rasio yang digunakan untuk memenuhi tingkat kecukupan pemenuhan modal yang memadai untuk menjaga likuiditasnya. CAR merupakan salah satu indikator kemampuan LPD dalam menutup penurunan aktiva sebagai akibat kerugian yang diderita LPD. Besar kecilnya CAR ditentukan oleh kemampuan LPD dalam menghasilkan laba, berdasarkan besarnya pertumbuhan laba suatu LPD. Semakin besar CAR maka kinerja LPD tersebut akan semakin baik. Konsekuensinya, akan meningkatkan pertumbuhan laba yang dimiliki. Hal ini disebabkan LPD memiliki modal yang cukup untuk melakukan kegiatannya. (Sapariyah, 2012) menyatakan variabel capital yang dinyatakan dengan CAR berpengaruh positif terhadap pertumbuhan laba. Sedangkan CAR pada penelitian (Sujana, I Ketut, I Made Sadha Suardikha, 2018), menunjukkan CAR tidak berpengaruh pada pertumbuhan laba.

\section{H1 : CAR berpengaruh positif terhadap pertumbuhan laba}

\section{Pengaruh Kualitas Aktiva Produktif (KAP) pada Pertumbuhan Laba}

KAP adalah rasio perbandingan Aktiva Produktif yang Diklasifikasikan terhadap total Aktiva Produktif. Semakin baik KAP berarti semakin efektifnya kinerja lembaga keuangan untuk menekan Aktiva Produktif yang Diklasifikasikan serta memperbesar total aktiva produktif sehingga akan memperbesar pendapatan, sehingga laba yang dihasilkan semakin bertambah. Penelitian yang dilakukan oleh (Pahlevie, 2009) variabel KAP berpengaruh terhadap perubahan laba. Sedangkan penelitian yang dilakukan (Sujana, I Ketut, I Made Sadha Suardikha, 2018), variabel KAP tidak berpengaruh terhadap perubahan laba.

$H 2: K A P$ berpengaruh positif terhadap pertumbuhan laba.

\section{Pengaruh Return On Assets (ROA) pada Pertumbuhan Laba}

ROA menunjukkan kemampuan LPD dalam menghasilkan laba dengan memanfaatkan aktiva yang digunakan dalam kegiatan operasi. Semakin besar perubahan ROA menunjukkan semakin besar fluktuasi kemampuan LPD dalam menghasilkan laba. ROA digunakan untuk melihat keefektifan lembaga keuangan dalam menghasilkan keuntungan dengan memanfaatkan aktiva yang dimiliki. Meningkatnya ROA menandakan besarnya pengembalian yang diperoleh oleh suatu lembaga keuangan. Suatu lembaga keuangan yang mempunyai ROA yang tinggi, maka akan semakin tinggi tingkat laba yang dicapai lembaga keuangan tersebut, kemungkinan suatu lembaga keuangan dalam kondisi bermasalah semakin kecil dan semakin lebih baik pula posisi lembaga keuangan tersebut dari segi penggunaan aset sehingga yang nantinya berpengaruh dalam pertumbuhan laba di masa depan. menemukan bahwa ROA berpengaruh terhadap pertumbuhan laba. Sedangkan (Sujana, I Ketut, I Made Sadha Suardikha, 2018) menemukan bahwa ROA tidak berpengaruh terhadap pertumbuhan laba.

$H 3$ : ROA berpengaruh positif terhadap pertumbuhan laba.

\section{Pengaruh Rasio Likuiditas pada Pertumbuhan Laba}

Penilaian likuiditas pada unsur ini didasarkan pada kemampuan LPD dalam membayar hutang-hutangnya terutama simpanan tabungan dan deposito pada saat jatuh tempo dan dapat merealisasikan semua permohonan pinjaman yang layak. Rasio alat likuid digunakan untuk mengukur kemampuan LPD dalam memenuhi kewajiban keuangan yang harus segera dipenuhi atau saat ditagih. Semakin besar rasio ini semakin baik karena kemampuan LPD dalam membayar kewajiban lancar yang dijamin dengan alat likuid yang dimiliki LPD. (Sujana, I Ketut, I Made Sadha Suardikha, 2018) menemukan bahwa rasio alat likuid tidak berpengaruh signifikan terhadap pertumbuhan laba. Sedangkan (Paramithari, Ni Made Pradnya, 2016) 


\section{Analisis Pertumbuhan Laba \\ (Studi Kasus Rasio Cael Pada LPD Kecamatan Sukawati Kabupaten Gianyar)}

menemukan bahwa rasio alat likuid berpengaruh positif terhadap pertumbuhan laba. Sehingga, hipotesis yang diajukan dalam penelitian:

H4 : Rasio Likuiditas berpengaruh positif terhadap pertumbuhan laba

\section{METODE PENELITIAN}

Penelitian ini dilakukan pada LPD di Kecamatan Sukawati, dimana data diperoleh dari LPLPD Kabupaten Gianyar. Beralamat di Jalan Kebo Iwa No.5, Gianyar. Yang menjadi objek penelitiannya adalah laporan keuangan terkait dengan rasio CAEL terhadap pertumbuhan laba LPD di Kecamatan Sukawati tahun 2015-2017. Metode penentuan sample menggunakan purposive sampling. Definisi operasional variabel sebagai berikut:

1. Variabel Terikat (dependent variable)

Pertumbuhan laba adalah rasio yang menunjukkan kemampuan LPD meningkatkan laba bersih dibanding tahun sebelumnya. Laba yang digunakan adalah laba tahun berjalan dari LPD di Kecamatan Sukawati periode 2015-2017. Pertumbuhan laba dinotasikan dalam satuan persen (\%). Pertumbuhan laba dirumuskan sebagai berikut (Harahap, 2015) :

Keterangan :

$$
\mathrm{Y}=\frac{\mathrm{Y}_{\mathrm{t}}-\mathrm{Y}_{\mathrm{t}-1}}{\mathrm{Y}_{\mathrm{t}-1}}
$$

$\mathrm{Y} \quad=$ Pertumbuhan laba

$\mathrm{Y}_{\mathrm{t}} \quad=$ Laba perusahaan tahun berjalan pada periode $\mathrm{t}$

$\mathrm{Y}_{\mathrm{t}-1}=$ Laba perusahaan tahun berjalan pada periode $\mathrm{t}-1$

2. Variabel bebas (independent variable)

Adapun variabel bebas dalam penelitian ini adalah sebagai berikut :

a. CAR adalah adalah rasio modal terhadap aktiva tertimbang menurut resiko. Cara menghitungnya (Pergub Provinsi Bali No.11 Tahun 2013):

$$
\mathrm{CAR}=\frac{\text { Modal (Modal Inti }+ \text { Modal Pelengkap) }}{\text { ATMR }} \times 100 \%
$$

b. KAP adalah rasio aktiva produktif yang diklasifikasikan terhadap aktiva produktif. Cara menghitungnya (Pergub Provinsi Bali No.11 Tahun 2013) :

$$
\mathrm{KAP}=\frac{\text { Aktiva Produktif yang Diklasifikasikan }}{\text { Aktiva Produktif }} \times 100 \%
$$

c. ROA adalah rasio laba terhadap total asset. Yang dimaksud dengan laba dalam LPD adalah selisih antara pendapatan LPD dengan biaya yang dikeluarkan. Sedangkan total asset adalah jumlah seluruh aktiva atau passiva. Cara menghitungnya (Pergub Provinsi Bali No.11 Tahun 2013) :

$$
\text { ROA }=\frac{\text { Laba Tahun Berjalan }}{\text { Total Asset }} \times 100 \%
$$

d. Rasio likuiditas adalah rasio aktiva lancar terhadap hutang lancar. Cara menghitungnya (Pergub Provinsi Bali No.11 Tahun 2013) :

$$
\text { Rasio likuiditas }=\frac{\text { Kas }+ \text { ABA }}{\text { Utang Lancar }} \times 100 \%
$$

Teknik analisis data menggunakan Analisis Linier Berganda.

\section{HASIL PENELITIAN DAN PEMBAHASAN}

Penelitian ini termasuk dalam jenis studi uji hipotesis. Objeknya adalah rasio CAR (Capital Adequacy Ratio), KAP (Kualitas Aktiva Produktif), ROA (Return On Assets), dan Rasio Likuiditas pada Lembaga Perkreditan Desa (LPD) di Kecamatan Sukawati yahun 20152017. Jumlah data yang akan dianalisis dalam penelitian ini yaitu sebanyak 84 data. 


\section{Analisis Pertumbuhan Laba \\ (Studi Kasus Rasio Cael Pada LPD Kecamatan Sukawati Kabupaten Gianyar)}

Penelitianini diawali dengan melihat statistik deskriptif yang disajikan untuk memberikan informasi mengenai karakteristik variabel-variabel penelitian, hasil statistic deskriptif dapat dilihat dalam tabel 2 berikut :

Tabel 2.

\section{Hasil Statistik Deskriptif Data Penelitian Descriptive Statistics}

\begin{tabular}{|l|r|r|r|r|r|}
\hline & & \multicolumn{1}{|c|}{$\begin{array}{c}\text { Minimu } \\
\mathrm{m}\end{array}$} & $\begin{array}{c}\text { Maximu } \\
\mathrm{m}\end{array}$ & \multicolumn{1}{c|}{ Mean } & \multicolumn{1}{c|}{$\begin{array}{c}\text { Std. } \\
\text { Deviation }\end{array}$} \\
\hline Y & 84 & -36.91 & 130.85 & 17.0756 & 26.12680 \\
CAR & 84 & 8.98 & 109.64 & 31.3975 & 15.56772 \\
KAP & 84 & .00 & 50.16 & 6.1627 & 9.12859 \\
ROA & 84 & 2.35 & 10.35 & 4.9113 & 1.67402 \\
Rasio Alat & 84 & 11.61 & 184.98 & 40.2433 & 20.42906 \\
Likuid & & & & & \\
Valid N & 84 & & & & \\
(listwise) & & & & & \\
\hline
\end{tabular}

Sumber : Data diolah

Analisis data akan dilakukan terlebih dahulu dengan uji asumsi klasik sebagai persyaratan untuk uji selanjutnya yaitu analisis linier berganda dan uji hipotesis. Sebelum dianalisis dengan teknik analisis linier berganda, maka model persamaan regresi harus lolos dari uji asumsi klasik. Berikut adalah hasil uji asumsi klasik yang diolah dengan bantuan program SPSS 20.0 for windows.

a. Uji Normalitas

Hasil uji normalitas dengan menggunakan Uji Kolmogorov-Smirnov dan analisis grafik

Normal Probability Plot dapat dilihat pada Tabel 3 dan Gambar 1 sebagai berikut :

Tabel 3.

Hasil Uji Normalitas

One-Sample kolmogorov-Smirnov Test

\begin{tabular}{|ll|r|}
\hline & & $\begin{array}{r}\text { Unstandardiz } \\
\text { ed Residual }\end{array}$ \\
\hline $\begin{array}{l}\text { Normal Parameters } \\
\text { a,b }\end{array}$ & $\begin{array}{l}\text { Mean } \\
\text { Std. Deviation }\end{array}$ \\
Most Extreme & $\begin{array}{l}\text { Absolute } \\
\text { Differences }\end{array}$ & $\begin{array}{l}\text { Positive } \\
\text { Negative }\end{array}$ \\
$\begin{array}{l}\text { Kolmogorov- } \\
\text { Smirnov Z }\end{array}$ & & .0000000 \\
$\begin{array}{l}\text { Asymp. Sig. }(2- \\
\text { tailed) }\end{array}$ & & .14 .63033309 \\
\end{tabular}

a. Test distribution is Normal.

b. Calculated from data.

Sumber : Data diolah 


\section{Analisis Pertumbuhan Laba \\ (Studi Kasus Rasio Cael Pada LPD Kecamatan Sukawati Kabupaten Gianyar)}

Hasil uji normalitas dengan 78 sampel dalam Tabel 9 menunjukkan hasil Asymp. Sig. (2tailed) adalah sebesar 0,296 >0,05, ini berarti bahwa data residual berdistribusi normal. Hasil ini juga diperkuat dengan melihat grafik Normal P-Plot of regression standarlized pada Gambar 3. Pada gambar 3 terlihat titik-titik menyebar berada di sekitar garis diagonal. Jika data menyebar di sekitar garis diagonal dan mengikuti arah garis diagonal menunjukkan pola distribusi normal, sebaliknya jika data tersebar jauh dari garis diagonal atau tidak mengikuti arah garis diagonal menunjukkan pola berdistribusi tidak normal. Hasil penelitian ini memenuhi asumsi normalitas karena titik-titik menyebar dekat dengan garis diagonal. Berikut adalah grafik Normal P-Plot of regression standarlized dari penelitian ini :

\section{Gambar 1.}

\section{Hasil Uji P-P Plot}

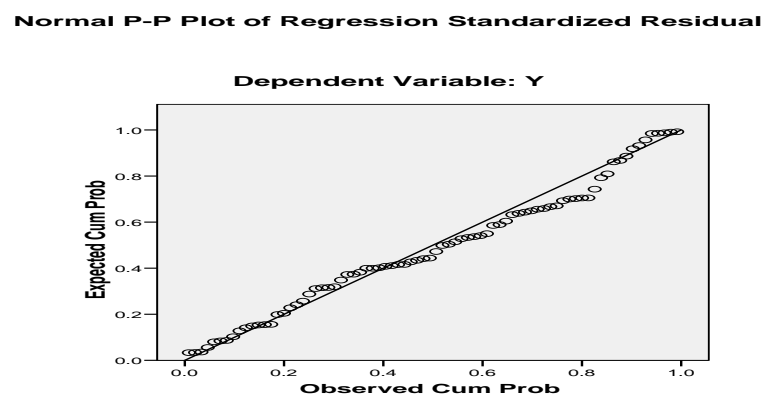

Sumber : Data diolah

Berdasarkan Gambar 1 diatas dapat dilihat bahwa data menyebar di sekitar garis diagonal dan mengikuti arah garis diagonal dan histogram pada Gambar 4 menunjukkan bahwa data mengikuti pola distribusi normal. Hal ini berarti modal regresi pada penelitian ini memenuhi asumsi normalitas.

b. Uji Multikolinearitas

Model regresi yang bebas dari multikolinearitas memiliki nilai variance infation factor (VIF) tidak lebih dari 10 dan mempunyai angka tolerance tidak kurang dari 0,1 (10\%).

Tabel 4.

Hasil Uji Multikolinearitas

Coefficients $^{\text {a }}$

\begin{tabular}{|ll|r|r|}
\hline \multirow{2}{*}{ Model } & \multicolumn{2}{|c|}{ Collinearity Statistics } \\
\cline { 2 - 3 } & Tolerance & \multicolumn{1}{c|}{ VIF } \\
\hline $1 \quad$ (Constant) & & \\
& CAR & .229 & 4.359 \\
KAP & .762 & 1.313 \\
ROA & .401 & 2.495 \\
& Rasio Alat Likuid & .511 & 1.959 \\
\hline
\end{tabular}

a. Dependent Variable : Y

Sumber : Data diolah

Berdasarkan Tabel 4 dapat dilihat bahwa tidak ada variabel bebas yang memiliki nilai tolerance di bawah 0,1 atau 10\% dan nilai VIF yang tidak lebih dari 10. Hal ini berarti bahwa tidak terdapat gejala multikolinearitas dari model regresi dalam penelitian ini.

c. Uji Heteroskedastisitas

Untuk mendeteksi ada atau tidaknya heteroskedastisitas yaitu dengan melihat grafik Plot antara nilai prediksi variabel terikat (dependen) yaitu ZPRED dengan residualnya SRESID. Deteksi ada atau tidaknya pola tertentu pada grafik scatterplot antara SRESID 


\section{Analisis Pertumbuhan Laba \\ (Studi Kasus Rasio Cael Pada LPD Kecamatan Sukawati Kabupaten Gianyar)}

dan ZPRED dimana sumbu $\mathrm{Y}$ adalah $\mathrm{Y}$ yang telah diprediksi, dan sumbu $\mathrm{X}$ adalah residualnya (Y prediksi-Y sesungguhnya) yang telah di-studentized. Jika ada pola tertentu, seperti titik-titik yang membentuk pola tertentu yang teratur (bergelombang, melebar kemudian menyempit), maka model regresi mengindikasikan telah terjadi heteroskedastisitas, sedangkan jika tidak ada pola yang jelas serta titik-titik menyebar di atas dan di bawah angka 0 (nol) pada sumbu Y, maka model regresi mengindikasikan tidak terjadi heteroskedastisitas. Dalam Gambar 5 berikut adalah hasil dari uji heteroskedastisitas

\section{Gambar 2 \\ Hasil Uji Heteroskedastisitas \\ Scatterplot}

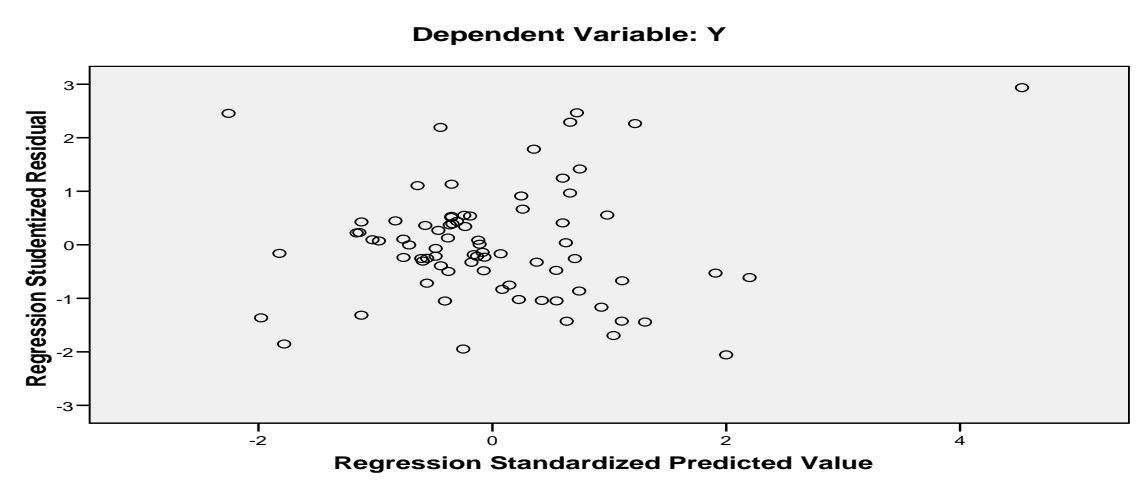

Sumber : Data diolah

Berdasarkan Gambar 5 terlihat titik-titik yang terbenmtuk menyebar secara acak, tersebar baik diatas maupun dibawah 0 pada sumbu Y dan tidak membentuk pola tertentu, maka dapat disimpulkan model regresi penelitian ini tidak terdapat gejala heteroskedastisitas.

d. Uji Autokolerasi

Jika suatu model regresi mengandung gejala autokolerasi, maka prediksi yang dilakukan dengan model tersebut akan tidak baik. Untuk mendeteksi ada tidaknya autokorelasi dapat diketahui dari nilai Durbin Watson (DW). Jika uji autokorelasi nilai DW > batas atas (du) DW, berarti tidak terjadi autokorelasi. Bila nilai DW < batas bawah (dl) DW, maka terdapat autokolerasi positif. Sedangkan bila nilai DW berada diantara batas bawah dan batas atas DW maka pengujian tidak terjadi autokolerasi atau terjadi autokolerasi. Dalam Tabel 5 berikut adalah hasil dari uji autokolerasi :

\section{Tabel 5}

Hasil Uji Autokolerasi

Model Summary ${ }^{b}$

\begin{tabular}{|l|c|r|r|r|r|}
\hline Model & R & R Square & $\begin{array}{c}\text { Adjusted } \\
\text { R Square }\end{array}$ & $\begin{array}{c}\text { Std. Error of } \\
\text { the Estimate }\end{array}$ & $\begin{array}{c}\text { Durbin- } \\
\text { Watson }\end{array}$ \\
\hline 1 & $.659^{\mathrm{a}}$ & .434 & .403 & 15.02582 & 2.020 \\
\hline
\end{tabular}

a. Predictors: (Constant), X4, X2, X3, X1

b. Dependent Variable: Y

Sumber : Data diolah

Dalam penelitian ini jumlah sampel adalah $\mathrm{N}=78$, dan variabel $\mathrm{k}=5$, jadi dalam tabel Durbin Watson seperti dalam lampiran, batas bawah (dl) adalah 1,52651 dan batas atasnya (du) adalah 1,74145. Hasil DW pada model regresi ini adalah 2,020, maka DW $>$ dl atau 2,020 > 1,52651, maka dapat disimpulkan tidak terjadi autokolerasi dalam model regresi penelitian ini. 


\section{Analisis Regresi Linier Berganda}

Teknik analisis yang digunakan dalam penelitian ini adalah regresi linier berganda dengan menggunakan alat bantu SPSS 20.0 for windows. Model regresi liner berganda doigunakan untuk mengetahui pengaruh variabel bebas yaitu CAR (X1), KAP (X2), ROA (X3), dan Rasio Likuiditas (X4) pada variabel terikat yaitu Pertumbuhan Laba (Y) Lembaga Perkreditan Desa (LPD) di Kecamatan Sukawati tahun 2015-2017. Adapun hasil dari regresi linier berganda dari penelitian ini dapat dilihat dalam Tabel 6 berikut ini :

Tabel 6.

Hasil Uji Analisis Linier Berganda

Coefficients $^{\mathbf{a}}$

\begin{tabular}{|c|c|c|c|c|c|c|}
\hline \multirow{2}{*}{\multicolumn{2}{|c|}{ Model }} & \multicolumn{2}{|c|}{$\begin{array}{c}\text { Unstandardized } \\
\text { Coefficients }\end{array}$} & \multirow{2}{*}{$\begin{array}{c}\text { Standardized } \\
\text { Coefficients } \\
\text { Beta }\end{array}$} & \multirow[b]{2}{*}{$\mathrm{t}$} & \multirow[b]{2}{*}{ Sig. } \\
\hline & & B & $\begin{array}{l}\text { Std. } \\
\text { Error }\end{array}$ & & & \\
\hline \multirow[t]{6}{*}{1} & (Constant) & -20.227 & 5.846 & & -3.460 & .001 \\
\hline & CAR & -1.276 & .227 & -1.035 & -5.629 & .000 \\
\hline & KAP & .803 & .210 & .385 & 3.819 & .000 \\
\hline & ROA & 9.189 & 1.619 & .789 & 5.676 & .000 \\
\hline & Rasio & & & & & \\
\hline & Likuiditas & .570 & .116 & .607 & 4.926 & .000 \\
\hline
\end{tabular}

a. Dependent Variable : Y

Sumber : Data diolah

Hasil perhitungan regresi linier berganda yang disajikan dalam Tabel 6 diatas, dapat dibuat persamaan model regresi linier berganda sebagai berikut :

$$
\mathrm{Y}=-20,227-1,276 \mathrm{X} 1+0,803 \mathrm{X} 2+9,189 \mathrm{X} 3+0,570 \mathrm{X} 4
$$

Dimana : $\quad \mathrm{Y}=$ Pertumbuhan Laba

$\alpha=$ Bilangan konstan

$\mathrm{X} 1$ = CAR (Capital Adequacy Ratio)

$\mathrm{X} 2=\mathrm{KAP}$ (Kualitas Aktiva Produktif)

$\mathrm{X} 3=\mathrm{ROA}$ (Return On Assets)

$\mathrm{X} 4=$ Rasio Alat Likuid

\section{Analisis Pengujian Hipotesis dan Pembahasan}

1. Pengaruh CAR (Capital Adequacy Ratio) terhadap Pertumbuhan Laba

Hasil analisis menggunakan program SPSS 20.0 for windows pada Tabel 6 dapat dilihat bahwa CAR memiliki hasil uji t sebesar 5,629 dengan tingkat signifikansi sebesar 0,000 lebih kecil dari 0,05 sehingga CAR berpengaruh negatif dan signifikan terhadap pertumbuhan laba. Hal ini berarti hipotesis satu $\left(\mathrm{H}_{1}\right)$ yang diajukan peneliti ditolak. Ini disebabkan karena ketidakmampuan LPD dalam menyediakan modal yang optimal dan kurangnya pengkontrolan risiko-risiko yang timbul dapat berpengaruh terhadap besarnya modal.

Dapat disimpulkan rasio CAR mengalami penurunan maka pertumbuhan laba akan meningkat, dan sebaliknya. Hasil penelitian ini tidak sejalan dengan logika penelitian yang dibangun sebelumnya, (Sujana, I Ketut, I Made Sadha Suardikha, 2018) dimana CAR bepengaruh positif terhadap pertumbuhan laba. Hasil penelitian yang sama juga diperoleh dalam penelitian yang dilakukan oleh yang menemukan bahwa CAR berpengaruh negatif terhadap pertumbuhan laba. Menurut Amri (2016) CAR yang tinggi dapan mengurangi kemampuan bank dalam melakukan ekspansi usahanya karena semakin besar cadangan modal yang digunakan untuk menutupi 


\section{Analisis Pertumbuhan Laba \\ (Studi Kasus Rasio Cael Pada LPD Kecamatan Sukawati Kabupaten Gianyar)}

resiko kerugian bank. Maka dapat disimpulkan jika CAR mengalami penurunan maka pertumbuhan laba akan meningkat.

2. Pengaruh KAP (Kualitas Aktiva Produktif) terhadap Pertumbuhan Laba

KAP menurut Tabel 6 memiliki hasil uji t sebesar 3,819 dengan tingkat signifikansi 0,000 lebih kecil dari 0,05 sehingga KAP berpengaruh positif dan signifikan terhadap pertumbuhan laba. Hal ini berarti hipotesis $2\left(\mathrm{H}_{2}\right)$ diterima. Arah koefisien regresi positif menandakan pertumbuhan laba LPD yang tinggi dipengaruhi oleh aktiva (kekayaan) dalam operasinya. Penelitian ini telah sesuai dengan logika penelitian, dimana KAP berpengaruh positif terhadap pertumbuhan laba. Hasil yang sama juga diperoleh oleh (Pahlevie, 2009) dimana variabel KAP berpengaruh terhadap petumbuhan laba. Jadi dapat disimpulkan semakin baik Kualitas Aktiva Produktif LPD berarti semakin efektifnya kinerja LPD untuk menekan Aktiva Produktif yang Diklasifikasikan, serta memperbesar total aktiva produktif sehingga akan memperbesar pendapatan, dan sebaliknya. Dengan semakin besarnya pendapatan yang dihasilkan maka pertumbuhan laba dari suatu LPD juga akan terpengaruhi.

3. Pengaruh ROA (Return On Assets) terhadap Pertumbuhan Laba

ROA menurut Tabel 6 memiliki hasil uji t sebesar 5,676 dengan tingkat signifikansi 0,000 lebih kecil dari 0,05 sehingga ROA berpengaruh positif dan signifikan terhadap pertumbuhan laba . Hal ini berarti hipotesis $3\left(\mathrm{H}_{3}\right)$ diterima. Arah koefisien regresi positif menandakan pertumbuhan laba LPD yang tinggi dipengaruhi oleh rentabilitasnya. Penelitian ini telah sesuai dengan logika penelitian, dimana ROA berpengaruh positif terhadap pertumbuhan laba. Hasil yang sama juga ditemukan oleh (Wijaya, 2013) dan (Paramithari, Ni Made Pradnya, 2016) bahwa ROA berpengaruh positif dan signifikan terhadap pertumbuhan laba LPD.

Semakin besar ROA menunjukkan bahwa LPD semakin efisien dalam menggunakan asetnya sehingga akan memperbesar laba. Meningkatnya ROA menandakan besarnya pengembalian yang diperoleh oleh suatu lembaga keuangan. Suatu lembaga keuangan yang mempunyai ROA yang tinggi, maka akan semakin tinggi tingkat laba yang dicapai lembaga keuangan tersebut, kemungkinan suatu lembaga keuangan dalam kondisi bermasalah semakin kecil dan semakin lebih baik pula posisi lembaga keuangan tersebut dari segi penggunaan aset sehingga yang nantinya berpengaruh dalam pertumbuhan laba di masa depan.

4. Pengaruh Rasio Likuiditas terhadap Pertumbuhan Laba

Berdasarkan hasil analisis pada Tabel 13, dapat diketahui hasil uji t Rasio Likuiditas adalah 4,926 dengan signifikansi 0,000 lebih kecil dari 0,05. Sehingga dapat dapat disimpulkan bahwa Rasio Likuiditas berpengaruh terhadap pertumbuhan laba LPD di Kecamatan Sukawati tahun 2015-2017. Artinya apabila Rasio Alat Likuid meningkat maka pertumbuhan laba juga meningkat, demikian sebaliknya. Hasil penelitian menunjukkan bahwa semakin besar Rasio Alat Likuid maka semakin baik kemampuan LPD dalam membayar kewajiban jangka lancar yang dijamin dengan alat likuid yang dimiliki LPD. Semakin likuid LPD tersebut kepercayaan masyarakat pada LPD akan meningkat, sehingga untuk jangka panjang pertumbuhan laba LPD tersebut akan meningkat.

\section{SIMPULAN}

Berdasarkan hasil penelitian, maka disimpulkan yang dapat dari penelitian Analisis

Pengaruh Ratio CAEL pada Pertumbuhan Laba Lembaga Perkreditan Desa di Kecamatan Sukawati tahun 2015-2017 adalah sebagai berikut: CAR (Capital Adequacy Ratio) berpengaruh negatif dan signifikan pada pertumbuhan laba, KAP (Kualitas Aktiva Produktif) 


\section{Analisis Pertumbuhan Laba \\ (Studi Kasus Rasio Cael Pada LPD Kecamatan Sukawati Kabupaten Gianyar)}

berpengaruh positif dan signifikan pada pertumbuhan laba, ROA (Return On Assets) berpengaruh positif dan signifikan pada pertumbuhan laba, dan Rasio Alat Likuid berpengaruh positif dan signifikan pada pertumbuhan laba.

Implikasi penelitian ini bisa digunakan acuan untuk Lembaga Perkreditan Desa (LPD) untuk memperhatikan faktor-faktor seperti Modal, Asset, Laba, Likuiditas untuk memperbaiki tingkat pertumbuhan labanya.

Keterbatasan penelitian ini hanya menggunakan Rasio CAEL untuk menganalisi pengaruh pertumbuhan laba diharapkan peneliti selanjutnya mengembangkan penelitian sejenis dengan topik yang sama tapi dengan mempertimbangkan faktor lain yang dapat mempengaruhi pertumbuhan laba LPD, seperti pertumbuhan ekonomi, umur LPD, tingkat leverage, dan lain-lain.

\section{DAFTAR PUSTAKA}

Dewi, Made Rusmala, I Ketut Suwarta, dan I. G. N. J. A. W. K. (2014). Analisis Kinerja Kesehatan LPD dan Pengaruhnya Terhadap Pertumbuhan Aset LPD Kabupaten Badung. Jurnal Manajemen Strategi Bisnis Dan Kewirausahaan. Vol.8. No.1. Februari. Fakultas Ekonomi Dan Bisnis. Universitas Udayana.

Harahap, S. S. (2015). Analisis Kritis Atas Laporan Keuangan Edisi 11. Rajawali Pers, Jakarta.

Pahlevie, N. H. (2009). Analisis Pengaruh CAR, NIM, LDR,NPL, BOPO Dan EAQ Terhadap Perubahan Laba (Studi Empiris Pada Bank Umum di Indonesia Periode Laporan Keuangan Tahun 2004 - 2007).

Paramithari, Ni Made Pradnya, I. K. S. (2016). Kemampuan Capital, Asset, earning, dan Liquidity Mempengaruhi Pertumbuhan Laba pada LPD Kabupaten Badung. Jurnal Akuntansi. Universitas Udayana.

Sapariyah, R. A. (2012). Pengaruh Rasio Capital, Assets, Earning Dan Liquidity Terhadap Pertumbuhan Laba Pada Perbankan di Indonesia (Study Empiris Pada Perbankan di Indonesia). Jurnal Ekonomi Bisnis Dan Perbankan, 18(13).

Sari, L. P. (2015). Analisis pengaruh Rasio Keuangan Terhadap Pertumbuhan Laba pada Perusahaan Food and Beverages yang Terdaftar di Bursa efek Indonesia periode 2009 sampai dengan 2013. Skripsi Manajemen. Universitas diponogoro, Semarang.

Sujana, I Ketut, I Made Sadha Suardikha, dan A. A. N. B. D. (2018). Pertumbuhan Laba pada Lembaga Perkreditan Desa. Jurnal Ilmiah Akuntansi Dan Bisnis. Vol.13. No.2. Juli. Fakultas Ekonomi Dan Bisnis. Universitas Udayana.

Wijaya, A. P. (2013). Analisis Rasio Keuangan Dalam Merencanakan Pertumbuhan Laba/: Perspektif Teori Signal. Ajian Ilmiah Mahasiswa Manajemen, 2(2). Retrieved from Http:// Portalgaruda.Org. 